\title{
ANMELDELSER
}

\section{KLAUS HØYER: Hvem skal bruge sundhedsdata - og til hvad? København: Informations Forlag 2019. 88 sider. ISBN 978-87-7514-5799. Pris: 50 kr.}

Alt, hvad vi foretager os, fra vi står op, til vi går i seng, er gennemsyret af data. Sociale medier, handel online eller indkøb i supermarkedet efterlader dataspor, som potentielt kan sige noget om vores adfærd og dermed vores sundhed. Sammen med de offentligt indsamlede sundhedsdata i Danmark om indlæggelser, medicinering etc. befinder vi os altså i en sundhedsdataeksplosion. Sådan sætter Klaus Høyer scenen $\mathrm{i}$ indledningen til sin debatbog, der i saglig essaystil reflekterer over muligheder og begrænsninger ved sundhedsdata. For hvad er sundhedsdata egentlig, hvad kan de, og hvad kan de ikke?

„Data skaber særlige måder at vide noget på “, skriver Høyer, og dette argument danner en implicit rød tråd igennem bogen, hvor kritiske spørgsmål til, hvilken form for viden data skaber, formidles med stor indsigt i et letforståeligt sprog. Som når statistiske sammenhænge mistolkes på det ukontrollerede datamarked som resultater og årsagssammenhænge på linje med medicinsk evidens, og populationsdata dermed oversættes direkte til individniveau. Eller når data opfattes som noget stabilt og upåvirkeligt, selvom registrering af data er en subjektiv proces; eksempelvis når den praktiserende læge, der presses til at udskrive antibiotika af en insisterende patient, der derfor registreres under ,lungebetændelse“, selvom vedkommende reelt er ramt af en forkølelsesvirus. Høyer påpeger derfor, at data kræver metodiske kompetencer, hvis man i analyserne skal kunne forholde sig til datas validitet. Her kritiseres det også, når data bruges som styringsredskab og i politiske visioner, hvor der ikke levnes plads til viden fra det behandlende sundhedsvæsens hverdagspraksisser.

Hvem skal bruge sundhedsdata - og til hvad? er den 14. bog i Informations Forlags debatbogsrække „Moderne Ideer“, hvor pennen går på skift blandt eksperter, der giver deres perspektiver på nogle af tidens største udfordringer. I bogens forord, der følges af fire kapitler, ridses linjerne op, mellem hvad Høyer kalder „databegejstrede“ og ,dataskeptikere“. De databegejstrede er optimistiske i deres syn på, hvad fremtidens sundhedsdata kan bidrage med af bedre og mere præcise behandlinger. Dataskeptikerne, derimod, fokuserer på individets rettigheder og på de mange faldgruber og risici for misbrug af data, som det relativt uregulerede private sundhedsdatamarked indeholder. Høyer argumenterer her for, at disse to lejre har så svært ved mødes om uenighederne, fordi ,,det datadrevne sundheds- 
væsen har elementer af et trossystem“. Her løfter bogen sig fra at give et (dog efterspurgt og kompetent!) overblik til at fremføre et argument om, at perspektivet på data som trossystem fremviser antagelser om, at vi ikke behøver at vide, om vi kan stole på kilderne til viden, og samtidig, at det kan skabe et sprog for det, som kan være svært at tale om. Høyer argumenterer her med empiriske eksempler og $i$ et letlæst sprog. Blandt andet giver han eksempler på, at data som trossystem indebærer, at vi måske godt ved, at skridtmåleren i telefonen ikke nødvendigvis måler rigtigt, men det giver os noget at forholde os til og op imod. Her er det nok, at vi tror på data. Derudover kan det være nemmere at tale om intime og personlige aspekter af ens private liv, når der er et gennemsnitstal at holde sig op imod. Følelsen af nedtrykthed, argumenterer Høyer, er nemmere at tale om, hvis patienten med en app kan fremvise grafer og tabeller over sit humør og bruge dette som udgangspunkt for en samtale med den praktiserende læge. Heri ligger samtidig en fare for, at data mistolkes eller overfortolkes af begge parter.

Når mennesker tror stærkt på betydningen af bestemte data, giver det data politisk magt og legitimitet, skriver Høyer. Det er i denne del af bogen, at det antropologiske potentiale står stærkest og nærmest kalder på studier af sundhedsdatas vidensformer, legitimitet og evidens i en kulturel kontekst. Heri ses også potentialet $\mathrm{i}$ data som antropologisk objekt på et mere generelt plan.

I bogens form ligger en forventning om forslag til løsninger, og denne del løser Høyer ved at give alternativer til, hvordan sundhedsdata kan og bør bruges. Særligt værd at nævne er Høyers konkrete forslag om at skelne mellem datagenererende algoritmer som beslutningsudløsende og idégivende. Dette, mener Høyer, vil stille langt højere krav til det videnskabelige belæg for brug af data i sundhedsvæsenet. Her anes en pragmatisk løsningsorienteret tilgang til et af sundhedsvæsenets største udfordringer, som bygger på Høyers forskning og ekspertise inden for området. Måske debatformen kan inspirere den klassiske akademiske tekst til også at turde blande sig og konkretisere løsningsforslag. Høyer viser i hvert fald tydeligt, at hvis ikke forskere tager denne rolle på sig, venter et hav af ikke-datakyndige, ikke metodisk kompetente private aktører.

Bogen er vellykket som indgang til det brogede felt om sundhedsdata og bør være obligatorisk læsning for enhver forsker, der bevæger sig ind på dette felt. Dette skyldes ikke mindst Høyers overblik og sikre argumenter, der er forankret i hans mangeårige forskning i data og teknologi på sundhedsområdet. Selvom debatbogsformen ikke er en klassisk akademisk tekst, fungerer litteraturlisten som en slags state-of-the-art om sundhedsdataforskning, og selve bogen kan også bruges som reference i projekter, hvor der ønskes et overblik over feltets udvikling og forskellige interessenter i en dansk kontekst. 
Alexandra Ryborg Jønsson

Cand.scient.anth., ph.d., postdoc

Institut for Folkesundhedsvidenskab, Københavns Universitet

John Brodersen

Praktiserende loege og professor

Institut for Folkesundhedsvidenskab, Københavns Universitet

\section{STINE KRØIJER: Figurations of the Future. Forms and Temporalities of Left Radical Politics in Northern Europe. New York: Berghahn Books 2015. 254 sider. ISBN 978-1-78238-736-7. Pris: 210 kr.}

Hvordan ændrer man verden, når man ikke har hverken plan eller konkrete målsætninger? Det er et spørgsmål, som denne bog meget fint besvarer. Krøijers ambition er at vise, hvordan venstreradikale aktivister gennem forskellige kropslige teknikker og performative sociale aktiviteter momentvis skaber sociale virkeligheder, der fungerer som alternativer til den kapitalistiske omverden.

I bogen følger man Krøijers deltagelse i aktivisternes liv, hvori hun er positioneret som medaktivist i det venstreradikale miljø, primært i København, men også internationalt. Gennem detaljerede etnografiske beskrivelser får man som læser et indblik i forskellige aktivisters hverdagsliv, herunder situationer, hvor de er ude at skralde - samle mad i en container bag et supermarked, forbereder fællesspisning, holder møder eller gør sig overvejelser omkring børneopdragelse og verdens politiske tilstand. Man kommer også med til mere spektakulære begivenheder såsom store protestmobiliseringer med tusindvis af deltagere, klovne, hjemmebyggede warriorbikes og enorme papmachéfigurer samt konfrontationer med politiet fulde af tåregas, taktiske formationer og knipler og også en dansende og larmende gadefest i København.

Gennem bogen lærer læseren, hvordan hverdagshandlinger tilskrives en afgørende betydning i det venstreradikale aktivistmiljø. Den måde, man klæder sig på, hvordan man skaffer sin mad og sine ting, hvad man spiser, hvordan man udfører beslutningsprocesser og i øvrigt omgås hinanden, bliver alt sammen forstået som vigtige politiske aktiviteter. For kun ved at man udfører disse handlinger på bestemte måder, kan en ikke-kapitalistisk, alternativ verden opnås. Her bygger Krøijers analyse blandt andet på Marianne Maeckelberghs (2009) begreb præfiguration, som betyder at arbejde for at opnå en bestemt fremtid ved at udleve den i nutiden. For eksempel kan man altså arbejde for at opnå en ikke-kapitalistisk social verden ved at leve sit liv efter ikke-kapitalistiske principper. Men Krøijers argument rækker ud over, hvad der rummes i præfigurationsbegrebet. I stedet fremfører hun en mere radikalt alineær forståelse af forholdet mellem tid og handling. Krøijer viser, at 
de venstreradikale aktivister forstår tid som en diskontinuerlig og uforudsigelig størrelse. Det vil sige, at fremtiden ikke ligger for enden af en række på hinanden følgende handlinger (der er ikke noget ,præ“). Den alternative verden, som de venstreradikale ønsker, manifesterer sig derimod i punkter. Det sker for eksempel, når det lykkes at tage mødebeslutninger gennem konsensus; når det lykkes udelukkende at leve af mad, man skralder eller selv gror; når det lykkes at leve uden for det kapitalistiske forsyningsnet. På baggrund af aktivisternes forståelse af fremtiden som noget radikalt uforudsigeligt og alineært fremfører Krøijer et analytisk begreb om fremtiden som momentvise figurationer.

Igennem hele bogen bliver aktivisternes egne forklaringer brugt som udgangspunkt for at danne en teori om tidsontologier. Med forankring i aktivisternes forklaringer om deres liv som markeret af skiftende perioder med henholdsvis aktivitet og optimisme eller passivitet og modløshed formulerer Krøijer en teori om tid som enten „død“ eller ,aktiv“. Ved hjælp af en række konkrete eksempler på måder at opføre sig på bliver læseren ført gennem dette argument. Når aktivisterne er mobiliserede og ,aktive“ (for eksempel når de skralder, spiser vegansk, opfører sig efter konsensusprincippet eller konfronterer kapitalismen gennem protester), lever de en anden verden, som på den måde findes. I perioder, hvor de er deprimerede, inaktive eller opgivende, er denne anden verden tabt, den eksisterer ikke. Fremtiden - og dermed tid mere generelt - kan således forstås, ikke som lineært fortløbende, men som momentvise sammentrækninger, der enten er ,aktive“ og findes, eller er „døde“ og ikke findes. Dette markerer en ontologisk forskel fra lineær tid, hvor handlinger bliver forstået som akkumulerende i forhold til fremtidige mål. Dette argument bliver særligt tydeligt i bogens fokus på mobiliseringen af store protestbegivenheder.

Bogens etnografiske beskrivelser zoomer særligt detaljeret ind på planlægning og afholdelse af massemobiliseringer omkring datoer (eksempelvis for politiske topmøder), hvor aktivisterne skal mobilisere sig i protestbegivenheder. Her bliver læseren ført gennem talrige møder og forberedelser i planlægningsperioden. Det er overraskende at se, hvordan planlægningen af sådanne protester reelt sker uden nogen plan eller egentlig proces (også når der er 100.000 deltagere!). Det viser sig, at der ikke er nogen konkrete fastlagte mål at arbejde hen imod. Selv efter talrige møder og forberedelser ender det med, at alle bare må gøre, som de har lyst til på dagen, hvor protesten afholdes. Lige så overraskende er det, at aktionerne alligevel „holder sammen“, når de endelig udføres, og ikke „opløses“ som følge af manglende overordnet strategi eller forskellige personers og gruppers individuelle initiativer. Læseren opdager i løbet af bogen, at protesterne findes som en affektiv synkronisering - en kropslig og mental samhørighedsfølelse - hvorigennem underelementerne (eksempelvis personer og undergrupperinger) kommer til at udgøre og føles som én samlet koreografi. I levende beskrivelser 